University of Louisville

ThinkIR: The University of Louisville's Institutional Repository

Electronic Theses and Dissertations

1932

\title{
Health and relief functions of the League of Nations.
}

Louise Meyer Barth

University of Louisville

Follow this and additional works at: https://ir.library.louisville.edu/etd

Part of the History Commons, International and Area Studies Commons, and the International

Relations Commons

\section{Recommended Citation}

Barth, Louise Meyer, "Health and relief functions of the League of Nations." (1932). Electronic Theses and Dissertations. Paper 1669.

https://doi.org/10.18297/etd/1669

This Master's Thesis is brought to you for free and open access by ThinkIR: The University of Louisville's Institutional Repository. It has been accepted for inclusion in Electronic Theses and Dissertations by an authorized administrator of ThinkIR: The University of Louisville's Institutional Repository. This title appears here courtesy of the author, who has retained all other copyrights. For more information, please contact thinkir@louisville.edu. 
ONIVLRSITY OF IOUISVIIIS

HEALTH AND RELIET FUNCTIONS OF THE IEAGUE OF NATIONS

\author{
A Diseartation \\ submittod to the Paollty \\ of the Graduate Sohool \\ of the Univerelty of Loulovilie \\ In Partial pulf1liment of the \\ Requirements for the Degree \\ of laster of Arts
}

Department of H1Btory

By

Loul ve Yeyer Berth

2032 
WEALYH AND RELIEP FUNCTIONS

OP THE

IEACUE ON NATIONS 
Fage 1

TABLE OF CONTENTS 
CONTENTS

Ohapter

Page

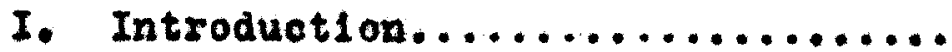

II. The struoture of the

Lengue of Hat1ons...........

III. The Roots of the Ilea1th Organd antion of the

Iosgue..................

IV. The Constitution of the

Health Organdzation

of the League..............

V. The Organization and

Yethode of the Heal th

Orgenlation..............

VI. The Lengue'g Ifforts in

International Rellef

Vork.......................

84

VII, Conelueton................. 
OHAPTER I

IARRODUCRION 
The aims, organisation, and workings of the Health Organization of the League of Nations as they are today could never have come into belng without a League of Nations. The ohlef alm of the League is to bring about better understanding and cooperation among nations. How the Health Organdzation 18 attempting to further this aim wi11 be brought out in the disousal on whlch f0110ws. First, however, it may be pertinent to Indicate the origin and struoture of the Ioague of Nations, since it is from this body that the Health Organization drawe 1.te powers.

We have become so nocustomed to thinking of the League of Hation a product of Woodrow W1Ison's presideney that it may be well for us to remember that the ldea that peace oould be attained by nome sort of en international organizetion was not nev one. The 1dew of organtaing an international group that would prevent wars and bring about international underatandIng was firat held by mer1c Cruce in 1623.1

\footnotetext{
Other plans, somewhat simliar, were get forth by the Duc de Sully in $1634 i^{2}$ by 11ilgm Penn in 1693 , $^{3}$ by the Abbe' Saint-Pferre in 1729,4 by Jean Jacques. Rousseau in $1769 ;^{\circ}$ and by Kant in 1795.

${ }^{1}$ Her bhey: Fisentiale of International Public Law, Page 67 Lower: International Government, Page 362 3 pugcani The Ieague of Hatlons, Page 212 Siower, International Corernment, Page 176 5uarburg! Lengue of Itetions, Page 23
} 
In 2899 the flrat Iague Conference wa held. Th1s was the first enuine more to be made by Buropane to bring about international cooperation among the tions. Howerer, internetional organization had not become strong enough to cope with the strons feeling of nationalion which came to a crisis juet before the World Far of 1914.

The record a glven above is proof enough that the Idea of a League wa not a oudden thought by a brilliant tategman but one that had been developing for years. The progreso that was made was instructire and without it our present league in 1 ts final form could not have been made. Howerer, our contemporary otateomen did make this one $b_{16}$ achlevement-they brought internetional organization down from the cloud and made it into a fearible and practicable organizetion.

Preceding the outbreak of the war, statesmen had begun in earnest to work on a plan that was no longer theoretical but practical. Theodore Rooserelt was the firet greet modern statesman to faror a League of Jations. He did this in 1910 when he took the Nobel Peace Frize and olectod as the subject of his 
addrese, "A League of Hatione." When the World War broke out in 1914, he returned to the oubject and, in a series of four urtioles, oyndicated in the New York TIwes and other Sunday newapapers, adrocated "A League of Vations for the Peace of Righteousness". to follow the Torld War. He said, "It would" be a derellet of duty 1f, after thic war, we falled to oreate auch an agency to prevent future world wars." After Amerian entered the war in 1917, Roomefolt again turned to the subject and continued to adrocate such a league In articles in The Independent, The outlook, and in hls book, Americe and the Yer.

W112lax Taft, also, wes an ardent supporter of the ldea of a league. The plan of League of Nation by the statesmen of the United States is baid to have had its orfin in the League to Enforce Peace, a body formally organized in Independence Hall in June 1915 wth $\mathrm{Mr}$. Taft its president. ${ }^{2}$ president wilaon flrst expressed his views concerning a permanent world peace organization in an udaress given on Yay 27, 1916 to the League to Enforce Perce.

Fisher, America's Interest in World Peace, fage 78
Haworth: The United States in Our Own Times, page 485 
In h1s address, $\mathrm{Mr}$. W11son expresed the hope that the belligerents (the United states had not yet become a party to the war) and the United states would join an es8oclation of nations which should be made after the close of the war. While the United States had men auch a Rooserelt, Taft, und W11son working out plans for a Laague of Bations, the other nations were not 1dle, Robert Cecil of England and General smuts of South Afrloa were at work.

The Corenant as it now exists was propared by a comalesion appointed by a conference of whlch PresIdent W11son was chalrman, al though he did not write the corenant. The comminsi on was made up of a group of experienced men of whow the most outetanding weres Lord Cecll of Great Britaln, General Bmuts of South Africe, and Leon Bourgeols of Prance. 1 These men worked over carefully all the drafts oubnitted by the parloue natione. The commisalon worked for ten seselone-efrom February third to Bebruary thirteenth. They worked out a project durine this time and preoented it in a peport to a plenary seselon of the Prellminaxy Peace Conforenee. On February fourteenth, thle draft was published to the world for suggestione. On March twentleth and twenty-rirst, a comittee of

\footnotetext{
Temperley: History of the Peace Conference, Vol, II, Fage 3 h
} 
the comblssion heard representatives of noutral states respecting changes which they desired. On the followlat days, Larch twonty-seoond, twenty-third, and twenty-fourth, three sebslons were held by the comalasion, and the draft revised to care for the gugestions offered to them. Finaliy. on April. tenth and elerenth, the commission gave the Covenant of the League its final form. The text wa formaliy adopted at a sesion of the Preliminary Feace Conference on April twenty-eighth, nineteon hundred nineteen. In editing the reault of the preliminary Feace Conference, the Covenant wa made to constitute Pert one of the Treaty of Peace.1. The work of this comalsolon was diffloult, as ito members were not in complete harmony. Some give 11 tie thought to the work at hand, they were more interested in drafting whit they considered the importent isoue of the day, the Peace Treaty. Some of the members thought it a futile attempt because of the other attempta and fallures at world peace. And still others were so anxlous to have League that they would not quibblo over detalls. W11son was of th1s group. In consequence, the Corenant was prepared in an acedemio way and adopted by the Peace Conference without rery 
eerlous consideration.

V11son 18 often spoken of as the "Founder of the Leacue of Nations," but this titie is only true in part. Wilson was the person who insisted that League must be created, and it was he who forced the "B1E Four" (England, France, Italy, and the United States) to put the League in the Fence Treaty made w1th Austrla, Germuny, Huncary, and Buigarla. Without the prossure and Insistence of President W1180n, the League a it exista today would not have come Into being. W11son's work with the comiselon was effoctire ond constant but not domintint.

The comodion of men who drafted our present League were not inspired to create a league by the 1deals of a league as held by the ploneer workers in th18 I102d, but they were inspired by their pasion. ate hotred for war. Out of the war came some very definite 1deas that had to be realized if our present c18111zetion were to survive. The only way for these alms to be realized was to create a league of nationa. These reasons for the existence of a Lengue are best expressed in a summary of the practical caupes of International Affairo in A History of the Peece Conference, from whioh the following are quoted.' 
1. The cause of negotiations in tho twelve day preecding the outbreax of the wax drew attention to the need for wo settled Counoll of the Iations responslble for the maintenence of peace."

2. VIolation of Belglum demonetreted the need for a more comprehensire guarantee of the sefety of enell nation. then could be furnished by amall treat1es botween a sroup of powers."

3. "Increased exhaustion of all1ed rosources during the last stages of the war foroed upon the Allies cooperation not merely in the formation of broad policies but in the detalled administration and execution of euch pol101es."

Out of the first set of consideretions the Aswembly and the Couno1I of the League were oreated, and the powers designated to them were a outilned In Articles 12 to 15. The second fuotor was cared for in the League in Article 10, in which article 1. set down the guaranteo of territoriel integrity. Article 16 obligates all members of the Leacue to enfores peace. Out of the third factor dereloped the Seoretarlat of the League which wae augreated to the composers of the Lengue from the prmotleal experience of International adrinistration that doreloped during the latter stage of the war. The secretariat was estebilshed In Article 6, Artioles 22, 23 , and 24 give the functions and powers of this body. These 
artioles mentioned are the most lmportant found in the Corenent. It $1 \mathrm{~s}$ in Article 23 that the Health Body of the League was formed ab a perranent part of the secretariat. 
CHAPTzar II

THE STRUCTULE OR THE IEAGUE OF NATIONS 
The League of Hetion provides for the followings

1. The destruction of autocrat10 power:

2. The discuselon and arbitration of the problems between nations

3. The peace of the world under constant International overaight

4. Disarmament

5. The rehabliltation of oppreased people

6. No more annexation of territory

7. The abolishlng of enforced labor

8. The publishing of all treatles made between nations

9. H1gh standard of labor, such as exist In the United 8tates, extended to all men

20. Cooperation of all Red Cross societles

11. All humane Instrumental1ties (11ke the conventions against the oplum trade) under the direction and control of the Ieague

The three bodles whlch attempt to carry out these provisions are the Assembly, the Counc1l, and the secretarlet. The Assembiy meets once a year at Genera and acts as the legislatire body. It is so conotituted that erery olf-gorerning otate that is a member of the Ieague is represented. Not only the self-governing Independent btates but the gelf-governIng colontes and domintona, such Canada, Now zealand, Australle, Indie, and South Afrioa, are 
represented. Each member of the League has three ropresentat1ves in the Acsembly, though eoch state hes but one rote. The Assembly does its work through -tanding comaltees, of which the most important ares the Budget Comalteo, the Conmittee that asalats in the admission of new states to the League of Nations, the Comaltee that selects the judges that serve in the World Court, and the Combittee that eelects the non-perwanent members of the Counc11. The Assembiy was chlefly created by the men who drafted the League to give all nations an equal chance to expose any 1rrogularity or plan of another nation againgt the offended nation. The Assembiy 18 a debeting body, a court of the public opinion of the world. The real power of the Assembly, other than moral, is two-fold. Its chler constituted power is that it has a chance to decide a question brought to it by the council. The question must, howerer, get a majority rote and this rote mat include all the representative of the nations who have rote in the councll. The other power of the Assembly comes if the nations want to amend the League. Such amendments must flrst bo unanimousy accepted by the Counoll and then pased by a mojority rote in the Assembly. 
The Counc1l meets three times a year and has fourteen members. A delegate is chosen from each of the member states, flve of which are pernanent member and nine, non-perment members whose term of off 100 18 three years. The permanent member states are: Great Britein, France, Italy, Germeny, and Japan. The non-permanent membera change from term to term. The chlef functions of the Council are to moke plans for reduction of armaments, to mediate in forelen disputes, and to recelve reports from mandatory powers. The Council is the executive organ of the League and all declsion made by the Councll must be by unanimous rote of all of its members. Nothing in the form of an active measure, no pol1cj, no recormendation with regard to the action of the covernments compoing the League, can proceed whout a unanimous rote. The Counc11 is a more important body than the Assembly.

Last but not least, comes the Socretarlat of the Ieqgue. This body is a permanent one. It has its headquarters at Geneva. The execut1ve body of the Secretarlat is oompand of a Beeretary from Great Britaln, Deputy from Prance, and three undervecretarleamone from Japan, one from Italy, and one 
Prom Germany. The body of the secreterlat is composed of eleven sections. The complete personnel is about fire hundred men and women. The purpose of the secretariat is to act in the capeolty of a civil servioe. Its work is in the field of pol1tica, legal, eonomio, and flnanclal information, mandates, disarmoment, ooctel problemo, and International socioties. Axticle 23 gave the secretarlat 1 ts birth and power. This Artiole give the League supervision over the execution of agreements with regard to the traffio in women and chlldren, and over the traffic in oplum and other dangerous drugs. It authorizes the League to try to maintain freedom of communioation and transit and equitabie treatment for the commeroe of all the member nations of the Leacue. Efforte to prevent and control disease are also made Then internetional ection is nccessary. Under this Article, the League is pledged "to secure end maintain falr and humane conditions of labor" in all countries. Because of the many powers Eiten to the Seoretariat as set down in Art1cle 23, a number of aubldiary organizations had to be created. The rork 1. carried on under two main comattees, the Advisory Cowndtee and the Technical Comittee. These Com- 
mittees in turn have establighed six permanent standIng oomaltees. The Technioal Comaltee has its work drided into the following heads, financial and economic effortsi transit and commications; intelleotual cooperation, and international health. It is wh this last diviofon that this paper will be most concerned.

Through the three bodies as outlined above, the League of Nation attempt to develop a wide internotional coopertion by bringate the world closer together in meny of its 1dealo and establishing oolldarity in matters of common interest-mealth, social and moral disease, and common economic progress. If the League of Nations accomplishes this, its creators and supporters have acoomplished a worthwhlle and lagting ochievement. Even if the League could not prevent another world war, it would have served a noblo purpose in attempting and, in many cages, accomplishing the ataming out of disease, the traffio In oplum, and the traffic in women and chlidren. 
CILAPTEI IIX

THE ROOTS OF THE WWATH ORGANIZATION OF THE IEAGUE 
The necessity of preventing and stamplng out disonse has always been a serlous problem to peoplo of all nations. The serloumes of the situetion partloulariy concerns them when they read ouch atatistics a that out of about two bijlion people. Beventy wlilion are sick all of the time und of these twenty-elght milion are needlessly ofck. ${ }^{2}$ Dlserse Io ueually consldered a matter for doctors rather than for diplowats, but epldemics, starting In a far-away country, may spread throughout the world. An influenze ware began in Spain and brought death to thouscnds of people in Americh. A case of omal1-pox in Canada gave rise to a virulent epldemio In Hinnesota and Hichigan. Typhus fever und leprosy entered the United State from Lexico. Trachom we Introduced Into our lerge clties from Europen citles. In the nineteenth century alone, six cholera plagues left their mark in European countries.2 These fects are sufflolent angwer to the question as to why the League of Nations should concern

\footnotetext{
Tobely: "For the Health of the World"--Current His tory, Hovember 1922

Zuanson and Hangon: Tropicel D18eases, Page 345
} 
1teelf with matter of public health and aocial welfare, when presumably its purpose is wholly and colely to prevent wars. The primary alm of the Laague of Nations 18 generally underatood to be the promotion of international pocos. Th1s, of course, 1. true, but its actirities are by no means confined to th1s work alone. The preamble of the League atates Its purpose "to promote international cooperation and to achiere international pecce and seourity," by certain principles oet down in the covenant. This sentence alone ohow that the framers of the League had International cooperation in mind the most important work of the League. They realized that international petce 1 effectirely promoted by whetever und tes the nations in efforts to bring about their oomon Interests. The League is now carry ing on many activities only remotely or not at all related to war, and as time goes on it wild assume more of this work. The foot io thit modern $11 f e$ is rapldiy orerfiowing national boundaxy 1ines. Government. are finding themelve confronted more and more with - ltuation. which no nation acting lingle-handed can meet. The se condition have come about mainly through the rapidity and rolume of our preaent-day 
tranaportation and comminlcation. As our nation have bocome loss Isolated and more dependent beoause of modern facilities, disea has become an international problem.

In oplte of the work done indiridually by each clvilized notion, disease could not be stamped out. Under this gy etem each nation acted alone and passed 1ts own regulations. D1sease was still rampant mainly because it wa impossible to force the bnckard countries to epol the tested and well-known san1tary regulations which have proved of ineatimable value in preserving the health of all the natione who praoticed them. Enlightened netions heve been rery succostul within their own countries in stamping out yellow ferer epldemics and cholere, whereas in the backward oountrieg these digeares are st111 ravaging the netires, because their only combeting weapon acalnst disease is e mixture of superatition, charm, and Fitohoraft.

For many yecrs netions attempted to stamp out and prevent disease individually. When new of an epldemic reacicd a nation, thet nation would adopt a rlgid quarantine polloy in which comerce from the infected stetes would be dented and in whloh 
poople and ship suspected of infection would be interned for an inconrenlent length of time. These measures usually came too lcte, for in many instances shipo with their pasgengers and cargo would have entered ports of nations not infected by the disease before news of the existing epldemic had been received.

Between 1851 and 1907 six international santtation conferences were held in Europe for the purpose of discussion of measures to be taken against epldem1cs. In 1893, 1894, 1897, 1903, 1907, 1909, and 1912, agreements were 81 gned. 1 The most important accomplishnent of the conferences held before 1907 was that a Superior Health Council was established at Conetantinople and a Sentary Larltime and Quarentine Councll of Ebypt was established in Alexandrie. The reason for the existence of these two organizatione was thet most of the epldemlcs which owept the world came out of the oriental and far-eetern countries. The work of these trio councilo wes becun with special measures and precautions to be taken with regard to the Suez Canal, Eryptian ports, the Red sea, and the Persian Gulf.

Buel1: Intermationel Relations, Page 291 
In 1907 an International offloe of Public Heal th, better known a the offioe International d'flyglene Fublique, was established. Its office was locctod at Parls and Ita princlpal occupation was to collect information concernine gublic health and especially infoctlous disense. The states participating in the offlce were divided into $81 x$ classes, and each stcte bore the expenses nccording to 1to classification. Th1s office was under the upervision of a complttee of delecateg, one deleGate from each state. Each state wa allowed a nuraber of rotes in the comittee univereely proportionate to the number of the class to whlch it belonged. In 3920, thirty-seven countries participated in tho. work of this office. ${ }^{2}$

In 1007 alx colonial powers held a conference at London. The conference vas called because the native tribes of xfrica were being ravaged and thouonds of denthe were resultins from tropleal diseases, the most important of which was eleeping slcloness. Th1 serm 1 a carrled by the taetse fly. The 
conference made certain resolutions about these conditions. In the following yeer, 1908, another conference was held to carry out these resolutions, but It fulled becuuse Italy and France objected to haring e central bureau established in Iondon. 1

In 2908 and in 2912. Bngland and Cermeny signed egreements to exchange all Information as to sleeplng aickness and to prevent diseased nat1ves fron crossing the colonlal frontlers. They also acreed to kill off a certain species of crocodile thet was auspected of carrying the disease.

Even though the Inited States hed attended the Internetional conferences held in Europe. representatlves also attended the Pen Americen conferences held durine 1902 and 1927. The first sanitary conference held in 1902 euthorized the organization of a Pan Americen Senitary Bureau at Warhington. Its duty wa to collect all data relative to the protection of bealth. In 1905 a convention was held to confer and pase measures to prevent the spread of cholere and yellow ferex. The conference laid down

$\overline{\text { Treaties of the United States, Volume II, Page } 214}$ 
provisione that alI Anerican states must notify alI countries of un infection. Defenstve nee bures were also teken by the conference. Out of these conferences developed thit is recarded as one of the most guccessful international health acreenente ever necoticted. The acreement veg sicned by the Anoricen atates on Horember 14,1924 and wa deaicnated "The Pan American Sanitary Code." I

The se attempto clearly show that natlons were avare of the Growinc menace of disease. Juat as the man conferences that were held by the nations prevlous to 1922 paved the way for a Leecue of Nations, so did these health conferences $1 \mathrm{a}$ the foundation for the creation of the Health Division of the League as It exista today. 
CHAPTEA IV

THE CONSTITUTION OF THE

HEAITH ORGANIZATION OE TIE IEAGUE 
In the early manthe of 1919 an epidemic of typhus was oweeplng Russia and poland as a result of tho World War. It Involved en extensive region, inhabited by millions of people. The Rusalan end Folis governments had broken down, consequently no sanitary measures were bolng enforced. Both Russia and poland were st11l at war and the refugees and moving armies were gpreading the Infection. This condition was beconine a serious mentace to all the surrounding Iuropean countries. The League of Red Cross Socleties drew the sttention of its constituent societies to the serfou epldemlo conditions in eatern Furope, and cormision examined the situation. This comission, of which Dr. Hough S. Cuming, Surgeon General of the United States, wa a member, reported that the task was beyond the means and resources of Bed Cross administration and of private voluntary organizations. As a result of this study, the counc1l of the League of Nations, on April 13, 1920, requested the Iondon Health Conference, under the chalrmanship of Viscount Astor, the Britloh Uinister of Health, to draft a sobeme of organization for the health actip1tles of the Ieague. The flrot recomendation of the conference was that a temporary epidemic combalon 
be otablished to cope with the serious problem at hand. This conference also drew up the following provisions which the members felt should be a part of the work of the Ilealth organization when it care into beinc. ${ }^{1}$

1. To advise the Leacue of Nations in matters affecting bealth

2. To bring administretive health authorities in different countries into closer relationship with each other

3. To orgunize nezns of more ripid interchange of information on matters where immedicte precautions agalngt disease might be required, and to collect informetion es to their fulfilment

4. To promote the conclusion of international agreements necessary for adminlatrative aotion in matters of health, and their revision when required, and to collect information es to their fulfliment

5. To cooperate with the International Labor office in matters affectine labor and health

6. To confer and cooperate with Red Crose and other olmilar socleties

7. To adrise, when requested, other voluntary orgenizations in health matters of international concern

In addition to recomending the epidemic conmiselon and making the above suggestions, the Iondon 
Conference suggerted thet the Faris office, established by the Unirersal Sanitary Convention slgned at Rome, December 9, 1907, be maintelned and thet 1 ta delegate be members of the League's Eeneri 1 comittee. The office International d'Hyglene Publique on April 25, 1921 decided that it could not be a member of the Eeneral comittee, because the Untted States was a nember of the office Internctional and at this time the United States would heve nothine to do with Leacue of Natjons; in fict, otrongly disopproved of it. On June 22, 1921, the second Counc12 of the Lengue decided thet in view of the foct thet the office Internationel could not particinate, a prorislonel Technical Combttee should be composed. There should be chosen fourteen nembers to eerve on this comittee, trelve of whon should be individuelIy Invited to sit on 1t. The persons chooen should be gelected on the strength of their technical qualIflcations and not beonuse of their netionality. Also, representative of the Internationel Labor Office and a representative nomincted by the Ieague of Red Cross Soofetien should be merabers of this Technical Cormittee. 
Whlle these resolutions of the conference were being worked out, the temporary epidemic combission, whlch had been established by the Council, was workIng all the time under the direction of Dr. Worman White. Thi comiesion coordinated the efforts made to deal with the epldomica in Poland, Rusgia, and the Baltic states. It nssisted the national authorities by placing at their disposal specialists, hospltal and medical supplies, and, In some cases, clothing and food. The work of this combsion was very gratifylng. The cases of typhus fever in the rarious countries in 1920-21 decreased to follows In Poland, from 157,000 to 45,000 ; in Rugsia, from $3,000,000$ to 600,000 ; In Rumania, from 45,555 to $4,834.2$

In the early part of 1922 , at the request of Poland, an International Health Conference met at Warsaw under the auspices of the League. Twentyweven Euxopesn countries attended, and al though funds were not sufficlent for the full procram to be carried out, closer oopperation resulted between

Rose: "Epldemle Control in Europe"-Review of Rerlews, July 1922, Vol. 66, No. 1 
the Ruselan and Polloh authorities. Also, opeotal oourses were organized for the training of the personnel engaged in the ont 1-epidemio carapalgn. And, more important than theae steps, there were the onitary conventiona drawn up between the countries of Bastern Europe, whlch collaborated the work of the health administration of the various countries. The seoond Assembly and the Council of the League accompliahed other steps in promoting a health organization within the League besides establianing the Technical Comittee. They made permanent the epldemic commission which had been temporary. They sent a comalsaion to Greece to fight oholera, typhoid fever, and small-pox, a very neceasary step because these diseasen were raging in Greece at this time. This condition arose from the faot that thousends of refugees, about 750,000 in number, had crowded into the country from ABia lilnor upon the advance of the Turkioh troops. A vaccination campalgn was organlzed by this comisgion with the belp of eight Greek dootorg and health inspectors. As a result of their work, 500,000 refugees 
wore troated and the infection was greatly lessened.1 A mixed comaltee, made up of an equal number from the ifealth cormitteo of the League and the office Internitional d'Jyene Fublique, raet in Furie for four du, s, frow jay 27 to June 2, 1923, and morked out tie plan of healti orgunization for the Loague. On July 7, 1923, the Council and the Aasembly approved and adopted the permanent health organization plan as worked out bj this jolnt committee. 
The health actiritie of the League of Nations are due to Articles 23, 24, and 25 of the Corenant, and from those articleot the following excerptg are taken.

Article 23, Gubject to and in accordanoe with the provialone of international conventions existing or heraafter to be agreed upon, the members of the Ieagues

a. w111 endeavor to secure and maintaia falr and humane labor conditlone for mell, wolbeh, anc children, both in their own oountries and in all countrles to which their comnercial and lndustrial relation extend, and for that purpose will establish and maintain the necesaary international organizations:

b. will undertake to secure just treatment of the native inhabltants of territories under tives control:

c. w111 entruat the Leasue with the beneral supervision over the execution of agreemento with regard to the traffic In women and chl1dren, and the traffio in oplum and other dangerous drugs:

a. w111 entrust the Loague Fith the general supervibion of the trade in arme and armuaition with the countries in which the control of this trafflo lensecessary to the common intereat;

- w111 make prorielon to secure and wintain freedom of communloations and of transit 
and equitable treatment for the conmeree of 211 members of the jeague. In this conneetion, the opecial necessities of the regions derastated during the war of 1914-1918 shell be borne in mind;

1. Will endeavor to take stepo in atters of international concern for the prevention and control of disease.

Artiole 24, 1. There shall be plaoed under the direction of the Ieague all internationel bureaue already eatablished by ceneral treaties if the parties to such treaties consent. Al auci interntional bureaus and all combsions for the reguletion of matters of international interest hereafter constituted shall be pleced under the direction of the Ieague.

2. In all matters of international intereat which are regulated by Eeneral conventions but wilch ure not placed under the control of international bureaus or commis- Lone, the Secretariat of the League shall, subject to the consent of the council and if desired by the partles, collect and distribute all relevant information and shell render any other asciotance which may be necesstary or deairable.

3. The Counoli may inolude as part of the expenses of the Secretariat the expenses of any bureau or commission mich is placed under the direction of the League.

Art1ele 25. The member of the League agree to encourage and promote the establishment and oooperation of duly 
authorized roluntary national ked Crose organlsetlone haring as purposes the Improvewent of health, the prevention of disense, and the mitigation of suffering throughout the world.

From thege Articles the Council of the League recelved 1ts powers to create Health Organization, and In 1923 the following organization adopted a Goneral Adrisory Health Councli, a Standing Health Committee; and a Health gection of the secretariat of the League of Nations.

The Comalttee of the office International d'Hygiene Publique octs as the Coneral Advisory Health Counc1l. The office International mede no changes in its conotitution or 1 ts functions and retained 1to Paris orcantzation. Its maln duties ares to consider, discuss, and adrise or report on questions which may be subritted to 1t by the Standing Health Combittee of the League of Nations; to inftiate and tranamit to the Standine Health Committee any question which it may consider will be adranced by such procedure; to keep in close touch with the Health Section of the Secretarlat of the League; and to exchange all document relating to 1 ts work. The connection between the League Heelth Organlzation and the Paris International office has one b16 
practical adrantage, namely, that the comeltte of the Paris office is a body of governmental representative Irom many countries, who by reason of their official character naturally form connecting links between the Heal th Committeo of the Ineague and the governments of the nember totes which they represent.

The Health Committee of the League is mede up of twenty members. The president of the Permanent Committee of the Paris office acts as head. Wine of the other members are appolnted individually for three years by a compltee of the office Internetional in woh a way that each state which is a permanent member of the Counc1I of the League of Nations 1 s represented on the Standing Health Comittee. The remaining members are chosen by the Counc1l of the League, after consultation with the Ilealth Commltee. These members also are appointed for three years. This committee may be supplemented by the addition of not more than four public health expert as assessors, these assesors being appointed by the Counc1l of the League of Wations on the nomination of the Standing Heal th Commitee and considered fully effective members.1

Torld Peace Foundation, Publication of 1925, Page 496 
All the wembers of the Heal th Comittee are medical apecialleta or officials in charge of publlc health gervicen. They are selected for their technical qualificitions and ther belone to vaxious countries in Burope, Lutin Ataerica, and the Par last. These wen do not represent thoir rencetive countrico. Because of tils arrangent their sclentific discussions are not hampejed by any political consideration. Sone of the men serving on the cormittec belong to nations that axe not even uembers of the deatue. One of the menbers of the Compttee now serving is a citizen of the United Stetes and is ct the head of the Bederal Jeulth Service of the United States. The Nealth Comittee ard the Heulth Organization are nonpoliticel bodies. The duties of the Ifenth Conmttee axe: to drect the heulth vork of the Leacue of Nations and trrougs a Hodical Diz ctor to aircet the work of the Hecith soction of the secreteriat; to consider ard report to the Council of the League any public health uestion concernine the League which may be gubsitted to it of insticted by the Stinding Health Comittee; to appoint special commitees to consider eny inuly, reseerch, or other gublic health matter and to add to such special sub-committees 
any outside person whose qualifications it may consider w112 further the purpose almed at; to forward to the presicient of the Conaittee of the office International d'Hygiene Iublique a jearly report relating to the work cirried out by the Health organization of the League of Nations duifine the proceding year. This report ciso sets out the quebtions with whlch the Standing lieal th Cormittee proposed to deal to the extent of its corpetence as aeflued by the Council and the sasemol: of the jeasue of intions. The decisions of the Jieulth Comittee tike the form of printed resolutions will ch are transmited to the furvisory Gouncil for its considoxution. These resolutions to not becone effective uatil thoy have been oubutted to and supported of the Lecient Council. The Council does not act upon thers until advisory oplnions have been obtained from the Advisox: Council. Thus, while the final deciaioa on pollciea of the Health Organization depends upon the Council of the Ieague, the Health Cormittee reall, shares its policies and program. This comittoe incets twice a yeur. The Jealth Jection is tho executive oren und is an integral part of tive League socretariat. The Iecil thection 1a de af of fifter public health 
opeolalists, eplaemlologlets, and otatioticians of varlous notional1ties. It ects under the ledical Director. The furctions and auties of the Health Section are thowe laid down by the sterdinc Iealth Comattee subject to approvel by the secretaryGeneral of the league of ratione. The rain work of the Health section conslste in collectine the information regulred by the different comlttees, in makIne preperation for conferences and stua: tours, and, by corregroncence ard pulicetions, In forthé a connectinc Iink betreen all who are erenced in research work on the salic prollens. The Health section is also becrine cenerally recognized as the guteble mediatoz body ror the solution of internationel differences that irise orer eanitaxy neusures. A typloal examle of this is a ganitury convention thet was rede between Iolend and Rumnie on Decerber 20,2922 , which included the folLowing article: "If eny dispute arisine out of the coplication of this contention cennot be settled by the contrectine etetes turouch diplonatic ohannels, thege states shril undertake by mutual agreement to resort to the mediation of the Fealth section of the League of Nations.". 
Conventions of thl s type have been made between Foland and Rumanla et Wersaw, December 20, 1922, between Germany and Poland at Dresden, December 18, 1922; between Latria and Poland at Warsaw, July 7, 1922, between Latria and the Rusgian Soviet RepubI1cs, and the soriet Republice of the Ukraine and White Russia at Tartu, June 24, 1922, between Esthonia and Latria at Tartu, June 24, 1922, between Poland and the Russian Sorlet Republics, and the Soviet Republics of the Ukralne and White Russia at Warsaw, February 27, 1923, between Czeokoslovalia and Poland at Warsaw, 1922; between Esthonia and the Rusaian Soviet Republico, and the Soriet Republica of the Ukraine and White Russta at Tartu, 2922, and between Bulgaria and the Serb-Croat-Blorene state in April, 1923.1

Ieague of Nations Treaty Serles, Number XVIII, Vol. 2 , Page 119 
CHAPTER $V$

TIE OAGANIZASION AND HEHODS

OF THE HEAITY ORGANIZATION 
The League of WatLons through the Health Organ1ration is achiering work of great importance and lastIne usefulness in the fleld of internationel hygiene. The Ilealth Section of the secretariat is astablished and hes becore en indiapenseble link between netion and nation. The Ecconplishment of the work of the Fealth orgenization up to this time refipots great deal of credit upon those nen who worked it out. From the beginning those in cherge heve recognized that Its scope of action Is Iimted, oven though it olalms to work in the world-wide fleld of health. They real1ze it is no ifferent from any other organization in the eyes of the nutions and the they must proceed with care in order to remin in cbove susDiolon or orfticlem from the netions involved. Eren in maters of hesith, a countr does not wont an organization to project its rolicles upon that country without getting proper authority frm the existing governwent. For these reasons the Health organlation he not sought to interfere in any country or to exercige any kind of superior control. Ita object has been to gupuly all countries with informetion which no country could easily obtain for thelf and to advise every country of dengers threatening in 
nelghboring or even in fer-distent states. A further object he a been the study of those conditions which exert an influence on health in all perts of the worla. In the Health Orginlzation's attempt to carr out tiose ains it has established and perfected a vat Intel11conce systen. Throughout the forld men trained to observe the slightest indlcation of a comInc afsease epidenic are placed in countries where such epidemics are likely to occur, and these men report any development to the Health section at frequent intervals. Their work is not only in the field of epldemic control in such diseases a typhold, cholera, and melaria but also in keeping constant watch for any manlfestation of disease or those condition which cre conduclve to the breeding and disentuation of aisease germo. Todey every Health Department in each nution in the world know in advence whet dinecra they must be prepred to foce. They know which of the ships cibout to come into their ports are infested with diseace, and they know elso the germ-laden areas from which their supplies come. The captains and officlals of unfpr also exe kept informed of the hyelenic cond1tlons of the ports to which thoy are seling. In this nanner the Beclth organtzation acts as a centrol nervous 
syotem, and 1 ts commigiong and workers ect in the canacity of nourones. Informetion is sent beck to the central orgenlation pith the sure relative rapld1ty and accuracy by these rorkers as a eensation of the sensory nerves in our bodies is tronsnitted to our central nervous gystem.

with this system under way it is obvious that disease epldenics will be leas l1kely to bring about ouffering to hundreds of people becaise under thi plan there 1 a no time for the development of the germe. Almost immediately uron the outbreak of a d1secse every country 18 marned and iruedictel boglns to take steps of precution. The Moulti organlation bolleve in the old adace, "forewarned is forearned." Today every health depertnent recoenizes that 1t $1 \mathrm{~g}$ 1ts brother's kieper. The tondency to walt until sach scoures as c:010ra and the jlabue have crosed the fronters is civine plice to the deternination to meet them and defgat then before they have time to spread. The TenIth Organization la not conoerned only with diseages as they occur in epidemics, but it 18 interested in wora heal. It coordinctos and ingtitutes the recessfin statiotios to get a xol oxas of the vorld's nelth. It follows 
oolentiflc research concerning public hetith and circulater 1te discoreries, it cooralnates and asolots the action of organizations such as the Red Cross Socleties, the Internationel Bureau of Public Health, and other gimilar institutions. It not only organizes perlodical and internetional conferences of soholars and experta but it calla conferences similar to the internctionel labor conferences. Finally, by gyatenatic propacunde it impresses on public opinton the necessity of individual and coljective rules and habits of health. 
The work of the Jealth Organization 1s guided in the in by the two following principles:

1. The organization confines 1tgelf to work of a practical nature and does not undertake ary purely speoulative research

2. It does not 1 toelf deal with preot1cal health problems unless they are International in character, by reason elther of the ncture and extent of the inveatigations required or of the measures necessary to combat epldemics

The Ilealth Organization doe not depert from these prinolplea unies government asks for 1 ts teohnical advice or asalstance; in such an event, It naturally does not at op to consider whother what It is asked to do accords abcolutcly with the rest of 1 ts work.

The Health orgenization carries on 1 ts detilled work by means of commisions. The se subsidlary organs are combing of experts appointed by the Health section. Some of these comrittees undertake research along the line of what 1 s belng published on all matters pertaining to health, others coordinate tire laboratory work carried out by the various inatitutes, and at111 others pursue epldemiological inculries by means of study tours or misgions. There are al wo comalttees of government representative who deal 
chlerly with mattera that require the direct cooperation of the aduiniatrative nealth gervice. Iho Orcanization also arranges from tiwe to time international conference for tile exhausitive investigation of oertain technical questiona.

The method mogr comonly used in coordinating the work of scientifio problems is to summon a committee of experto to draw up a program. The investigations are then diatributed amond a nuruber of competent scientific institutions wiose airectors meot at regular intervias and, if necerary, vary the program. When they have completed theli task, a final meting is held at which a jolnt report is prepared embodying their findings. Soke comblttee carry out inquiries on the spot and go from country to country to corpare the methods of apylyine certain Bpeolicic health net ures. As a rule, howerer, the fealth Oxganization appoints a sincle investigator, or one of its merbers is attached to a scientific mission already conotituted by the countis concerned. The work of the Health Division is aivided into three main sectiona: Dpidemiologicil Intelligence Service, the Eaucational work of the lealtin Organdzation, and the Technical Work of the Health Organization 
In the rarlous flelds of preventive medicine.

The Temporery Epldemlc Comiselon, established in 1920 by the Counc1l of the League of Natione to fight the epldemic raging in Poland and Eussia before the present flealth organization was formed, made to the Health Authorities two leading sugbestlons: first, that there should be establisied an 1ntell1cence service sufflclently complete and comprohenstre to seep in constint touch w1th conditions in all

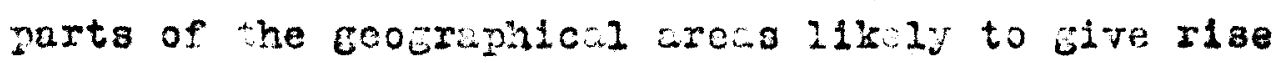
to, or be affected by, epldemic diseasca; and, second1y, that this scrvice should be such tikt information as to conditions anywhere might be commiccted to the central orgnization almost fnstunty. These sucestions were made $b_{*}$ tho Comisufon when thes realized thet the officiency of prophy 1 ctic meagures taken alone the russo-Folidh Santar. Cordon was maln1y depentent on the recelpt of pront and filz information on the outbreak and causes of cpldomics on woth sides of the frontier. Sonethling had to be done about the ge ficte if the rork of the Cormscoson ras to be successful. As a regult, the councti of the seague of rations in 2921 estibitered tie whideniolocical Intellience sorvice. It flas task, aftcr the one 
mentioned above, was that of collecting and tibulating a.1 arallable information in regara to the prepalence of certuin epidemic digeages in bastern Europe, with apecial reference to to phus, relapsing fever, and cholera, in Kussia und Foland. It also made a retrospective survey of the heclth situation In Rusis with the aid of the soriet autnorities. Thl Informetion was published in several volumeo covering the yeuro 1921-1922. In 1922 the kockefeller Poundation granted the Health Comaittee finincial aid In dereloping its epldertological intelifgence bervioe. Th1 appropriation of an annual grant of $\$ 32,840$ from the Internetional Health Board of the Rockefeller Boundation enabled the Committee in July 1923 to iseue the Lonthly Eplaemiological Report. 2 Ihlo Foundition has ance increased tia appropriation to fav. beginning with the year 1925 , for the intexcinunge of publis health personnel.

since the firat Honthly Epldemiological Report of the Health seotion, the service has been Grudually Improved so thet it is now possible for tine service to obtaln and publiah the latest inforition each 
month. The Report has become an invaluable ald to all health authorities. In 1923 the firat annual report wa publlahed on what ere called "notifiable disenses," and the first monthly report on the occurrence and previlence of such disenses was 1 soued in July 192:. The Annual Report is made up of the llonth1y Reports which ere checked and supplenented. The material for the Reports is furnished roluntarily by the public health services of the various countries and citles wherin such informetion is avallable. Orlginally, the main object of the EpldemiolocIcal service was to supply prompt information to the authorities of each country on the health situction. in nelghboring countries. In a very short time, however, the experts working on this service reallzed that this information could be put to even gracter uge if it were coordinated. Coordination of this work would enable Inveatigations to be made into the geoexaphical and seasonal distribution of diseage and the Influence of climatic conditions. Then this coordination began, the worker were confronted with a serlous difficulty--that of compuring information from a country with on adequate statiatical oervice with that from a country thet had no adequate otatiatical service. 
As a reoult, the Epldemiologtcal servioe was foroed to akn atudy of the atatistical rocords of enoh country so that the data publisined oy the variou countries could be intelligently used. Th1s work done by the Epldemiological Intelligence Service has been invaluable in waklng netional statiotico more efficient and useful.

Beblde the Epldenfologicil service loouted at Genera, there is the Eastern Jipldemiological IntelIIgenoe Center located at Singupore. ${ }^{2}$ Thia Center 10 more often referred to as the Far Eastern Burecu. It owes 1ts origin to the Japanese nember of the Health Comltee in 1222. He realized the usefulness and success of the Service in Geneva and therefore suggeoted that a similer one be potablished in the Far East. A member of the Ipidemic Commasion was inmediately sent to study conditions. His findincs were reported to the Heal th Committee which then recommended the estailishment of the Bureau in the Fur Bast. to the League Counc1l. In 1925 this Buretiu wa established at singapore. The central position of thi port is exoeptionaliy farorable, as it 1 s a port of call for praotlcally the whole of the maritime trude between Chlna and Japan and the Jear Eest, Africa, and Europe. Health Year Book, 1925, Page 619 
The mein function of this Bureau orielnelly was to keep in constint touch with the different health acninfstrions in the Far Eest, Eethering from them epiderifologicel information and disseninating it in a veckly code despetch, by ccible or wireless, to thege administrations and to Genera. In Exrope, plague and cholere are rare disenses, ind the only Gulned an entronce into Rusait as a resalt of war and rovolation, but hey are ver prevelent in the eastern countries, partioularl in Ind1a and China. Consequently, these recions are dangerous sources of infection to their nelichoring countries. Outbreaks of these disenses in Japnn and Jave where they are not previlent brought to the attention of all Eastern countries the necessity for guaruntine mescureg. They begen, therefore, to cooperite immedately wh the Bureau when it wa esteblisied by giving finenclal a $1 d$ and rapid trinsmingion of information desired by the Bureau.

In the eorly day of the Bureau, it kept in comrunication $v i t$ thint -five forte; at the present time It comunicates with one hundred fift porte. They are scattered throughout the Indian and Facific Oceana, from Alexandria and Cape Town on the Weet to the Fanama Canalzone on the sast. In frot, it isin constant 
communication with all Eastern ports of and importanoe. These potts Inform the Jurocu by telogriph at least once $\varepsilon$ week and oftcrer, when necesar, the number of cases and decthr caused by epidemlos. Roports are also made of quarintimos set or lifted wine varioue countrics and of the departure and courise of infeoted vessels. The Burew then inforris e.ll porta of the approaching infested vessed wind in tilis we the countries are able to teke the necesich precultions of quarantine before they becone infected. In 2927 the bureeu had an agreerient with thirtj-ive Fir-iastern Iieclth Adminfetrations $\mathrm{y}$ which it wes fracdic tely. notifled of the arrigal of infected shlys in ay of

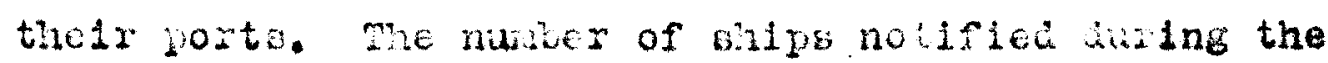

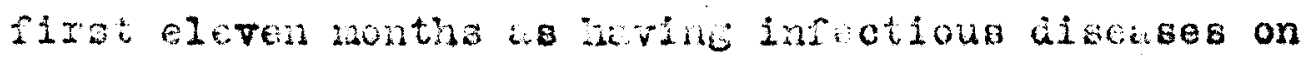
voard was one hundad shats-tro. This inforstion

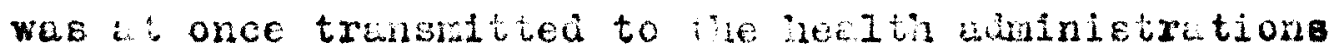
concerned. The ralue of thi a ervice fo best 11zustrated by he followine occurrence. In 102 : the Bu-

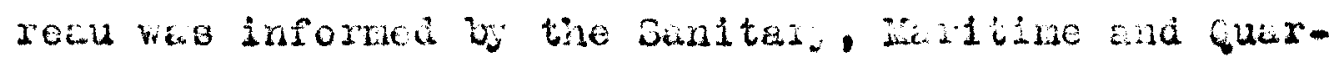
antine Council at Acxanarie in recid to the Hedjaz pilerimere. At the disbianent of these plierims,

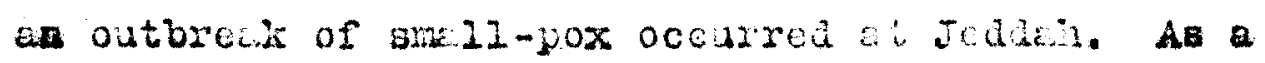
regult, elollteen pileriri ahis vere repuited to the 
Eastern Buresu a belng infected w1th sme12-pox on their arrivi at rasious ports. ${ }^{1}$

The Eastern Bureau also teleereph by code a weekl: Bulletin to Gencti and to the Lastcra Mealth Authorgties concerning the fnformetion sont in by those ravious countries. The code negace 1 s supplemented weokly by rore detalled and additional reporto by mail. The substance of these reports increasea in valde as a wdor range of information becomes avallable through stesd Improvencnt in the sinem of reporting and trinsmisston of these nessweo. These

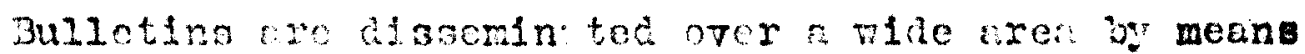
of the rno. The reekly orockesting of opldemlological inform tion 10 alod by the Dastom 3ureau is now insured by ten sta110ns, and one stetion brocdeats 1t deily. The anthouties in Indo-chine, Janan, and Gemeny aro been good onough to place their stations at the disposal of the Bureau for this yupoce.2 While the Instern Bureau of the Erlderiologicel Intclligrnce surfice concerns itself for tho nost part

\section{Lower: International Government, Page 421 \\ ${ }^{2}$ Secreterlat of the League of Nations: Ten Years of Worli Cooperi.ion, 2uge 237}


W1th the spreading of information concerning infected ports and shlps, its work to be effectlve has had to consist also of knowing the best method of disinfeotion and quarentine. To do this it collects and distributes informsion on the health eçupment of porta. It acts as an intermediary between the health admin1stretions of the countries to which 1 ta ophere of action extends. The Health Adninistrations send representetives each year to the sessions of the Advisor: Counc11. These meetings have been held at Singapore, New Delh1, and Java. At these neetings the delegatea are civen an opportunity of exchanging views on the subject. As a result of one of these mestinfs, the Eagtern Bureau wes aked to me an investigation into the efficlenc of oral racoinetion against cholera and d sentery. Research work wa widely done in Indie and Slam, end the findingepprored most beneflciel--the conclusion arrired at boing thet oral vacoination egainst cholera is almost as effective as racolnetion by gucutaneous infeotion. This is only one exmple of how the Eastern Bureau bets as a coordinating center for solentifle inpeatigations. The Bureau al so acts as an intermediary between a laree number of laboratories in the Fast and Far Eost 
For the exohange of experimental anfmals, becterial stains, and raocines.

After starting merely as an offlce for the exchange of epidemiological Intelligenoe, the Bureau has now become not only a connectine link between health authoritieg in the Eastern ports of the world, but also a centar for the coordination of scientifio research. The Bureau locontrolled by an Adrisory Counc1l consiating of delegates representing health administrations of the Far East. Up to the present time it has been largely financed by the Rockefeller Foundation which eranted it one hundred twenty-fire thousand dollars for a period of flve years beginning at the time of 1 to origin. Health Administrition from varlouscoountries have also contributed to 1 to support, and it is hoped that eventually it will bo aupported al together by contributions from many gorernmenta. 1

The Epldemiological Service at Genera has done other important things beside setting up the Bureav at Singapore. One of 1ts most outatandiag services 18 that of atendardizine the Norbidity and Yortality Statistica. In February 1924 the Health Comalttee set up oeveral committees of opeciallats to otudy the

Wyervi Mine Years of the League of Hationa--1920-1928, 
conditions. The maln points on which the compltees succeeded in obtalning the strndardization of statisties vere on stili-births and rules for the unsform deterninution of the cruses of deaths in cases of severil conomitunt diseases. All governmente bive now copted the seme definition of the trin "stiublthn," and a few conmon rules for the complation of statistios reluting to stlli-birtis. This agreement makeg it possible to compare the flowres furnished by those countries on the birth rate, fertility, and infant mortally, the retes being now oslculated in relation to the nurber of live births and not to the number of totel birtis. To illustrate how the compittee's work on causes of decth clecred up stitistical tables on this subjoct, the following incldent is civen. The Compttee found thet in sore countries where a death occurred from tiberculosig followine wooping cough, it was included in the tuberculosis statistica while in other countries it was complied as one of the death resulting from whooring couch.

The cormittees workine out the etandardization of stetistice held meetinge in 1923 and 1924 and included all the dirctors of the derocraphic services in the principal European countrias. Study tours were held in 
Sw1tzarland, France, The Netinerlands, and in the three Scandinavien countries. At a neeting in 1925 a numbex of common rules were drawn up relating co the reciatrition of the causes of deaths, and gyecial emphasis ma lasd on the neceabibj fox leevin the particulars entered in the civiz register seperate from the medick date olven in the deuth certificuteo. This reguletion ves mide to safeguri professionel sccrecy end hence heve the cortificutes relir ule. The work of the Comittec of Experts uniez tile Lyideniolog1 cal Intelliecroe Scivice ha been elok, but it heo echieved roy rerik rable resulis. The slon jogrebs In rueny cases has been due to the fict tiat in a number of countries the acceptirig of any new reculations intolved chenece in legislation tind in custor. Also, the only materiel saliable for them to work with wa documents complled durine the de fif fift jecrie. However, the Comelttee has now froposed and published a manuel for oxch country eivire the dine dinciple followed in colloctling and plesentlue deroerighio data. This menuel has mede it poseible to interpit correctly

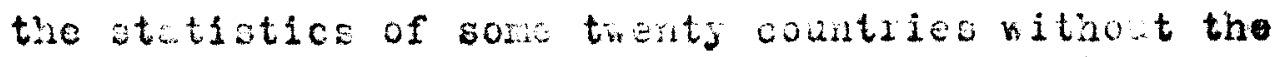
nooesity for lenetiay resectoh in librarios. The Eplaemiological Iatelligence Service has also 
made many epldemiologlcal invest1g tions, which inoluded Inquiries into the heilth conditions in the Wkxeine, into the eptdemlology of cholera in 3ritish India, into cerebro-gpinel meningitis in Prucsia. Into the morbidty and mortelit die to scarlet fever, and into her Ith concitions in certuin islincis of the Southern Facific. Since 1929 the Nonthly Roport of the Evidemfologicel sertice has included resilts of these inquiries and $a$ bibltocriphy roletine to the most important infoctiong diseesos and those which are most lorortant et the time of publication. These ourre: $s$ heve corared work in diphther1s, gmal1-pox, typhus, sorriet fever, end infontile paralveis.

Next in Importence nfter the work in the epldemlologles fleld, comes the Educrtiond work of the Tenlth orgentzation. ${ }^{2}$ one of the duties specified for the Health section 1 s to egtabligh closer relution between the adminiotretive herith exthorities in the deferent countries. The Health section nerform this dit $y$ by otcbilining colloctite study toir and Indiplduel ussions, by offering Internaticnal Courses in Hyclene, and by cotoblishing a Combaton on Iiducation in wglene. In addstion, it publighes the Irternotional Heal h Year 3ook.

\footnotetext{
Seorotariat of the League of Nations: International Health Year Book, 1925, Page 605
} 
The Health Section realized at the outset of Its work thet hyciene is primerily atter of educetion, and that this princlple applies not only to the seneral public but to health officials a well. The IlekIth Committee reallzed the immediate necessity of 1mproving the troining of the techntclens of the varlous countries. The first thing done in this direction by the Committee was to publish pamphlets on the organlzetion and working of the public herith service in various European countries. These publictions contain data on the administrative regulations, health legialation, and princinal health problems of those countrie and supply informetion on the coopertition of private associations with the public health authorit1es.

As the Health section realized that hyclene is a Ilving and growine aclence and the the publishine of the pamphlet fuat described above wes not enough to keep the authorities informed of the progress being made, it derised a plan by which this service could 60 on in a more permenent way through the publication of the International Year Book. By studying the mortal1ty table and new health measures introduced, one find in this book a record of the progress made each 
Year in flghting the principel diseave. In 1925 the first Health Year Book was published. It covers reports from twenty-seven countries, treating such subjects as birth and death rates, Infant mortility, public health budgets, derelopments in health adminlotration and logislation, cempaigne ggainst the socalled soolal diseaseo, curative medicine, water supply, sewage, hyglene of dwellings and schools, and phy aical culture.

since it was declded by the Health section that hyglene is primerily a ter of education, those in charge realized that it was nocessiry for the techniclans to learn the practical application of hyglene a well as to do the book work and laboratory research on the matter. The authorities believed that this education oould be given best by havine atudy tours. The objeot of the study tours is to afford the of flclale in charge of the national public health gerrloe an opportunity of meeting one another, of freely exchanglng riews on technical questions, and of prof1ting by each other' experiences. The orgentzation of these study tours began in October 1922. They were made possible beoause of the olose relations of the Leacue Secreteriat with the virious heal th authorltieg. 
The necessury financiel cid was again forthcouing

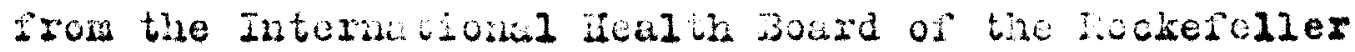

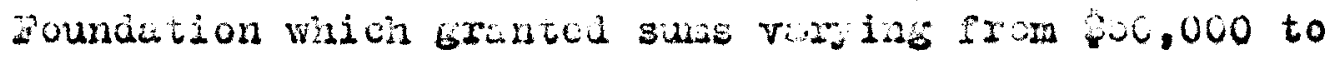
or 5,000 annually for tinese tours. 1

The tou-s have been orbinized in virious way, oove for jublic health officials, othore for specialiato in tuberculosia, infant bieiene, school hyglone, the nerlth alninistration of ports, demogribic statiatics, wd any others. 3y 1930 six handred officials belonglat to stitea winch vere menoers of the Lodicuc, whi also to certain non-meaber stitca, such as the United utates of ituerica, and Lexico, hud participated in these interohanges of newl bex ponnel." Wearly all countrits in Duropt, as well as Isitin

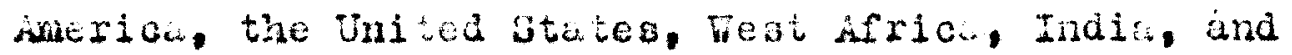
Japin havi ueen visited and hove sent offichals to the atudy tours. These collective interchanes beun in october 1322. After a study tour is over, the members olose with a conference and series of lcotures at Geneva. During 192 , these intercianges were altored

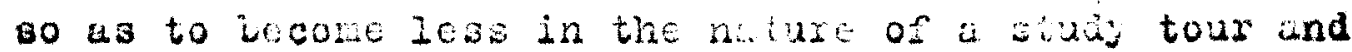

Tyera: Nine Years of the Lecgle of Wotions, Fage 207 ${ }^{2}$ Secretariat of the Ieague of Nationat Ten Years of World Cooperition, Fage 238 
more In the nature of internationed courses of advanced trainine in public heelth and hyglene. For example, an Interohance of specialists in industrial hyglene has now begun. The men who particlpate in this gtudy tour are unually labor inspectoxs. The last conference was attended by men who represented Russia. Belgium, France, Great Britaln, Japan, Holland, Czeckoslorakla, Poland, the Serb-Croat-Slovene state, and the United Stctes. The meetings were held at Genera at the Iengue Secretariat and at the International Isbor 0ffice. The field of study wes methods of hyglene used in the varlous industries in the geveral countries represented. 1

From 1922 through 1928 a totel of thirty-one interchanges was held. Such interchanges were held In all parts of the world. From 1922 to 1924 one hundred geventy-gix persons of one hundred twenty-81x nationalities participated in them.

There here also been individual misions orgenlzed by the Health Organl zeition to engble health offlcial to study those services in other oountries for which the netional authoritien felt the need of

World Peace Foundation, Pamphlet Ser108, 1926. I.8ge $30 \%$ 
a spectalfet. These missions may be for the purpose of elther oclentific or laboratory research and are gent out by the Herith scction. A procrim of 1nstruction 1 s drem up by the Yealth section vhich takes Into ecount the helth and sociel conditions preve12Ine in the officinls own country. These miselons beEan In 1926 and have been successful in strengthening the selentific ties between furope and distnnt countries like Japan, Indla, ond South Americe. Japanese sclentiats have been able to come and work in Europe end describe the regults of their investigetiong, and Western sclentiots heve had almiler opnortunities in Jipanese institutes.

With a simlar object in viev, namely, that of strengthenine the tiea of coordinotion in heslth work, the Health orgenlation becen in 1927 to offer two International courses of higher instruction in biefiene on technical guestions. These courses ore held in Parl and in London. The lecturers come from oll purts of the world, and the medicel offlcers who ritend the courses belong to twenty different $n$ tlonalities. The se theoretics a courses are always completed by a proctioal atudy tour through a large number of European countries. 
The Health section has concerned itself not only wth direct action in regard to education but it has done a great deal in the way of coordinating the work of all educctors on hyblene. Th1s work wa begun as early a 1923. On Jenuary 11 of thet year, the ilealth Committee esked the vedical Director to collect information from the universities of America, Europe, and Japan regardine the otudy of medical and social hyglene. On February 20,1924 , the committee appointed a comission to examine the information collected, to continue the incuiry, and to make recomendation as to the courses of study which in 1 to optnion would be most likely to yield the highest value in public education both from the scientific ard practical points of view. The commision worked out a complete procram with reference to courses of instruction. Through this comasion on Education in Hyglene, a bond of cooperation has been set up between such national inatitution a offer this ingtruction to doctors. The idea of this coordinetion is not to set up a uniform program for Ingtitutes of Hygiene, for, after all, national conditions releting to medios practice and soclal medicine must be the primary consideration. The 1dea is to give the directors of the verious 
national inotitutes an opportunity of reeting and exchareing expericnces.

The first meoting of this comnission on zducation in Hygiene and Freventive Nedicine occurred in 1927, when sesgion which took the form of conferences between the directors of sohools ofppublic health were held. Thio first meetine was held in connection with the inauguration of the new Institutes of Budipgest and zagreb. The directors of the Prague, Warsaw, Rio de Janefro, and Sao Paulo Inst1tutes took part, as well as opecialists from Berlin, London, Paris, and Bologna. The meeting was also attended by representatives of the Rockefeller Foundation and by the founder of the first public heolth faculty at Johns Yopkins University in Baltimore. The questions most discussed by this croup were the ostablishment of a special curriculum for instruction in hygifne, and the importance of the toaching of preventive medicins. Arrangerent were also made at this conference for technical cooperation on such questions a the supply of drinking water in villages, oral vacolnation against typhold fever, and the prevention and treatment of scerlet fever. The educational work of the Health Section cannot be too hichly profsed, as the benefits arisine from 
these missions, study tours, and conferences are not confined to the particlpants--their students, the universities in which they teach, and the medical world of the countries in which the: live all profit by them. The benefits of the educationel work are also shared by the health officials of countries visited.

The third grouplng under which the Hoalth organlzation carries out 1 ts work is in the technical Pleld of Preventive vedicine. As the work of this nature grew, the Health comittee found it necegsary to distribute the work anong its mombers ind, in certain cases, it forced to turn to gpecialists. The combltee carries out this technical worl through comissions which it appoints. A member of the Committee is appointed as the herd of exch of these commissions. The result of the work of the cormission Is turned over to the Health Committee. One of the dootors in the Heolth Section of the secretariat acts as secretery of ecch commission. ${ }^{2}$

There heve been rony of these commisatons set up since the health work has been carried on by the League, and they continue to erow in number each year. It would be Imposible to trace the work of each of 
the commlssions, but the work of a few of the most important ones will be discussed. Among the most important commissiong appointed to carry out the techniosl work of the Health Organization are: the Kalaria Commision, the Comissiong on Sleeplne Sickness, Tuberculosis, Cancer, Small Pox and Vaccination, Leprosy, Kables, Infant Hortality and Child Welfare, Proteotion of the Bilnd, Traohoma, and the Standardization of Sera.

The Proriolonal Heal th Committee appointed a malaria sub-comittee in January 1923, which became the Malaria Commisaion in 2924.1 It was one of the flrst to be set up on the technical work. It was not up to carry out an inquiry in the prinolpal centers of the disease. The reason for this inquiry wa that melaria wes fust syreadine in Ruesia, In the Balken countries, in poland, and even in Italy, due to mierations of populations, poverty, privations of all kinds, and algorganization of the medical services. The Lalaria Comalgsion vilted Yugosiavia, Greece, Bulgaria, Rumania, Iussia, and Italy and was accompanied in each country by a locel speciallat. After thls first inquiry, the combesion came to the following conclusions: that all persons having the

\footnotetext{
Beoretariat of the League of Nations: International Health Year Book, 1929, Page 1470
} 
disease must be thoroughly treated for a prolonged perlod of time; that all cases should be troced down; and that the population of all infected countriea should be instructed on the means of prevention. After this inquiry, however, the commission did not consider that it had aufflolent knowledge to give an opinion on various other anti-malaria measures, suoh as those relating to the destruction of mosquitoes and the carriers of the disease. It was therefore decided to ristt Syria and Palestine to find out the effect of the measures applied in those countries. In August and september, Spain was investigated. After these extensive studies, the commission drew up a regort in which it set down its views a to the best method of fighting nalaria in Europe. In this report it empasized the fact thet the treatment of patients, even from the standpoint of prevention, is of primary imrortance. Due to the high price of quinine, which has been found to be the most effective remedy, the treatment is very expensive. This was a serious problem for the comission to face as it realized that quinine was the beat remedy in cases of malarla and that the diseane arread in very poor distrlets, for the most part, where the people found 
It Impossible to eet enough money for this costly medicine. The combasion did not stop meriy with It f findinge but 1mmediately began etudies and experiments on the extraction and treatment of other moterfal in order to find a less expensive elbst1tute for quinine. Quintne comes from the baxk of the anchorla tree whlch grows very blowly and has to have a special soll and climatic conditione in which to thrive. This is a slow process, and the commission reallzed there could be 11 ttile done to speed it up; experiments were therefore begun on certain secondary alkalolds of anchovia bark which had not hithorto been used. These could be obtained at much lower prices. Experiments were cerried out under strict conditions in hospitals in Ital, Rummie, Spain, and Yugosiavia to determine the effect of certain mixtures of alkaloids (quinetum). These experiments were conducted over a period of several yecrs and as a result it was found that certain alkelolds have curative ralues equal to that of quinine. As a direct result of these studies made by the commision, these cheap products can now be used extensively by clinlcs, thus oomewhat oompensating for the insufficient output of quinine for medical requirements. 
During the tour in Eastern Europe and the Balkans, the commission was shocked and astonished by the scarcity of doctors ariliable with an adequate knowledge of ant1-malaria meagures. To overcome this difficulty the comisgion in 1926 began the organization in Hadiourc. London, and Faris, of a theoretical course in malarlology. Wis lecturo course wa followed by practical instruction at the antimajaria stutions and centers in Italy, Spain, and Yugoglavia. In 1728 a School of lialariology was opened in Rome. In addition to redical instruction, coursea are also given here for engineersadiagttculturists pertininge to the study of drainage and the reclatming of marsh lands. Since the beginning of these courses, two hundred fifty students have attended them through scholerships ersated by health organfzations, the Rockefeller Foundation, and the varlous corernments. The Ileciti Organization Grants fourteen scholarships annuslly to thege coursea. 2

The Lalaria Comisoion ves originally appointed to carry out inguiries into the incidence of malaria, into 1ts epidemiology. Into the world's requirements

Secretariat of the League of Nations: Ten Years of vorid Cooperation, Page 248 
for quinine, and into the problems conneoted with its manufacture, production, and distribution. The investieation, hovever, Erew to much lareer proportions. It took in the relitionsing of river deltas to endemio walcirla, tine Influence of rice fielos in furcpe, the role of enfmid, the recult of liainage deusures, the result of rascoses arected against adult mosquitoes, the value of the seoondity alkaloids of anciovia a a suostitute for ciandne, and the estavishant of courses to instruct the doctors in the causes and care of maleria.

The inalaria comiseion vegin its work with a few outstanding proolems, unt as it carried on its investigations, its nozk orew to eleantic proportions. It his veen thorouenly siccesaful in stampins out ard in finaine a les expensive cure for the malady.

Another comilssion that was appointed in the eariy day of the jealth Organtzation was the Commi-

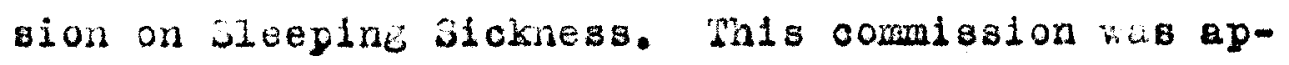
pointed as soon as line ieal th orgatacion cane into existence for the jurpose of atudyinio sleepind olckness in tquatorial frrica. The combisaton first gathored all the stetistics and docunents reliting 
to the d1sease. Wext, a conference was held in London, and all the colonial minlaters of the countries concerned met and agreed thet certain measures be adopted by all the countries holding possessions in Africi. The me measures included the following: that every native must have a passport to pass from one colony Into another, and that all countries having African colonles should adopt a standardized method of reglotering the cases and deaths occurring from sleoplng d ckness. This conference also sent a commisaion Into Africa to atudy the causer, simptoms, and developments of the disease.

In 1926 and 1927 , an International Erour of opeciallots, pald with money ralsed from the countries whioh had colonies in Africk, started work at Intobee on Lake Victoria. As a regult of this work and the work of the conference, the combingion was successful in colleoting important information. It made recommendations that an international agreement should be drawn up as to the supervision of the morement of natives, as to the treatment of the disease, and to preventire measures, such as olearing of buthes and draining of ewamps. 
In 1928 a conference of government representat1res was hold in Paris to consider these recomendations. Wot oniy vere the recomendations accepted, but the conference recomanded further that the African laboratories rork in conrainetion with tho intestigation of the Health Orcanization of the Ieague.

Work on the ndministratine and ranufecturine of small-pox vacine has also been cired for through the technical work of the Health Organization, A commis- Ion was appointed to investicete this subject when it we found thet in many countries punlic opinion wa acolnat the vaccination of children. This situation developed when it ras reported that ceses of nervous lesions hed occurred in children after the recolne had been adminjatered. This situation, of courge, wa very serlous one, because the small-pox vacclne had been very auccessful in stamine nut the disease end if this condition wa pllowed to continue without an investigation it wa feared by the nealth authorities that the amell-pox vecine would not be administered and the disease would en in the upper hand agrin.

The Cormisgi on begen its work by obteinine all detalled inforption rosalkie from tie countries in 
which the acciaents occurred. An investigation wa made by the comisgion on tige nethois used by the manocturers in preperinä, testinä, distributing, and apolyins the vacclne. The potency of the reocines was tested and statiatics vere kept. me findinsa of this comiasion vere very gratifyinc. After careful exaralnetion, they cane to the conclasion thet the method of preparation and the potency of the vaccine had no relition with the fact thot children dereloned such nerrous lesions sa had been reported. The Comisaion also pointed out the rare number of cases of encephetis in proportion to the total number of wila an inoculated. I auggestion was made that to arold encephatis in chlldren they be racolneted before they becane a veir old; this ronld prevent their hoving hed time to nequire a latent infotion which might lead to a vecinel accident.

whis finding of the oommsion was rery raluable because the statistice of the Ipldenlological service proved vory defindtoly that countries wich do not compel their citizons to be vecineted heve a very high rate of ocourence of the disenso. It in ebsentlal that erny coution should be tekon by the Health Organlation to provo to all backard countries 
the necesity of preventing disease by racoines. This could not ve done unless they were convineed that the racolne was not more harmful than the chance of having the disease.

A Comission on Ieprosy was also crested by the Health Committee. 1 Leprosy as a disease in Europo and the Unlted States 18 of little Importance because there are but a fow isoleted cases; howerer, in South Anertca and the verlous Eastern countries it is a reul plague. It is sald that in British India alone there are ono million lepers. The old way of segregating the lepers or imprisoning them for life in a colony is still practlced in many countrieg. Because of this dratic treatment, the unfortunate Individuals who have the disease conceal it ar lone as possible. In tils way they inf ct man others before they ere finally corced to seek medical ald and then in most case it is too late for medical sclence to be of much help to them. The Commision sugested that a more humane treatwent be given and that dispensarles be set up to gire treatment to beginning ccses. The commsalon also suggested that a cempeign be held in all countries infested with the disease to inform the people of prophylactic measures to be used in the prevention of the dieosse. 
In 1929 the Combiselon sent 1 ts seoretary on a study tour of those countries where leprosy is chlefly provelent in Europe, Britioh India, South America, the Phillipines, and Japen. He collected information as to the means of comunication of the disease and the beat treatment to combat 1t. As he traveled through these rarlous countries, he explalned to the local experts the riew held by the comalselon. There are no stat1st1ce araflable at present as to the success of the work of the Commlssion, but they will undoubtedly be forthooming at a later date.

The technical work of the Health Organization does not concern itgelf alone with infectlous diseases but appoints comittees to study infant mortalit; and onlld welfare. There has been a great lent of study and time put on these problems by the indiridual natIons, but the statiat1cs gathered by the Health organization on infent mortality indicated so serlous a stuation that 1t was felt necessary to make an inrostigation. The otatistios showed that infant mortallty (ohlidren under one yeur of age) accounted for one-tenth of the total number of deathe.1

Seeretariat of the League of Nationa: Ten Years of Worid Cooperiation, Iate 245 
In 1926 the Health Organization appointed a committee of experts to investigite the causes of infant mortality in certain selected parts of the world. This Inculry was necessary in order to probe deeply Into the causes. Eaoh country is bues yeurly a mortal1ty table, but the Ilealth Organization felt that a more uniform and eccurate picture could be obtained If a group of experts all used the same culding principles. The inrestigation of the committee was carried on in Germeny, Italy, Norway, and the Netherlands. In each of the Be countries two urban comanties, one with a high mortality rate and the other low, and two rurel commities were chosen a laboratorles for the work. The reoults of thls study were very enlighten1ng. It showed that the mejority of deatho were due to st121-b1rths and premature births for two principal reasons--elther that the proper pre-netal care had not been fiven or that the obstetrical treatment was faulty. The next important cause of chlld mortallty was found to be diseasos of the reaplratory tract and Inteatinal traot. After the combittee made the se findings, it turned its attention to the study of immunization against the Infectious diseases that later cause resplratory trouble. The diseases that 
give rise to this trouble are diphtherla, scarlet fover, whoopine couch, end meksles. In esch country the combltee collected all axperlences thet rere to be had on the Irmunization process. The commission also dealt with the question of training all medicul people and nurses in the pre-nate 2 and post-netal care of chiliten.

After the extensive work of the commlssion, it complied and turned over its statistics to the European health authorities. This piece of work was so viluable that the 3outh Americen authorities asked thet an investlgetion be carried out in thris country. In 1927 a conference of South Americen experta was held at Jontevideo. Invertigetions vere carried on by the pban used in Iurope. The investiction was held in Braz11, Chile, Areentine, and Uraguay. In 1930 another conference hald w1th the hope that another study extending to other South Amerlcen republics could be made.

In addition to the very valueble work of these comalsglong along the line of trohnical investigitions, the close cooperative ties that have been formed between the experts of the verlous countries is of Ereat importance to the Lecgue's continued existence. 
The Yealth Organizotion In 2921 appolnted a Fermanent Standrirds Comalesion. Thls vas necessary because all countries vere using seruma and anti-toxino for rarious alseases but the standarde of the serume used were widely different in the rrtous countries. Thls coused a serlous condition to arise, for serums obtalned from one country were used by the doctors of another. To 1liustrate-a doctor who wes ccustomed to administering one thousend German units of E certrin standerd would get ver foor results if he used one thougand Americun wits, as the Amoricen unit were found to be one-third the size of the German unit. The comission invedikt ly sot to vork to define and adont atandard units in the preparation of certiln medicel serums. The commisgion, since it is a permenont one, ig constantly crrying out its work as new serums and now anti-toxins are discopered. A certain stendra for e perticular serum la Aereed upon and then submitted to rellable private resecurch laboratories. The reants of the reserroh are tien crefully studind by a croup of experts. When these experts arrive at a standard unt, besed on preatetcrmined methods of comprison, they turn it ores to one of the lare public leboretories such sa the pasteur 
Institute of Puris or the FVelenic Iaborator of Washineton and acke that particuiar iaboratory respongible for tive preservation of the stand:rd. The laboratory which receives this information aots as the distributing agent for the Ieal th organization. It diatributes the stundird units to the scinntific laboratories, boti covernmontal ani commercind, go that they may male up tholr erades in internetionel units rather tian in the unit of certaln country. All covernments now require that gerums be measured in interntional units.

This compission of the Health Organization has also mede resecrch studies in the matter of seri, with a view to the standirdization of out-diphtheretio serum and dintheretic ant1-toxin. Research has also been cerried out regardine the use of ingulin, the prepertion aged in cases of dicibetes; digitalia, the tonlc usca for heort diserse; and obstetrical drues. Beside the statioticel, eplderiological, eduoational, and technicil work of the Health Organization, it has begun rork with the snclel inourance organizatlons and the public health services, During the past I1ve years a Erowine number of atater has adopted sociel insurance. Thla has broucht the attention of 
the rarioug governments to the fuct thut great handicops, both social and financiel, are placed on thetr citizens by preventible disewses. The public health departments of ech of the countries care fur thi vork, but due to the increasine cost of firtifr educintion snd bycicnic control, the insurunce cownies have hed to helr betr the cost of exrense. In $192 \%$ a mized conmis ion vas frod to etud the bet nethods of coopcration. The cormittec consisted of repregfitatives of 1nsurance organizations arpolated by the Internetional Is bor office and of medicul officera eppolnted by the Heelth orecnizetion. Smiler comissions vere alco set up to dan vith the sepirite branoh$e$ of the work. One sub-comittee, for cremle, worked on the rrevention of tuberoulosis, enother on the vevention of venereal disceses. A ctudy tour of Cermany and Austrie vas held to discover the practici? regulto of verlous forms of cooperction. The triue of the vork of these cormittees is in the exraneior of public health rork and in bringine ebout the contect between curative and yreventive medicine.

The Health orenizetion also vorked with the Internetionel Inbor office vhen a resectch vies made in connection with puetule in ceses of enthrex. ${ }^{1}$ The

\footnotetext{
Secretarlat of the Leacue of Nations: International Health Year Book, 1926, Page 1125
} 
disease 1 often contracted by workers handing hides and infected sins. Th1s work was oarried on through study tour by a mixed comalssion made up of medical and Industrial experts.

The Health organlzation prides itself on the fact that in the ten years of 1 ts exlstence it has cooperated with the following organizations of the Leagues the Advisory Commision for the Protection and Welfere of Chlldren and Young People, the Transit Organlzation (santary conventiono), the Economic Organization (reterinary quertions), the HIgh Comissioner's Office for the settlement of Bulgarian Refugees (oompaign agalnst malaria and oyphilis among Bulgarian refugeos), and the Health Conmittee in 1 ts work in giving teohnicel advice to the Oplum Commission.

The publio health authorities of all countries hare gained weterlally from the work done by the Epidemlological Service of the Health Organization and from the technical services rendered by the organlation. The public authoritles have the priv11ege of asking for experts to carry out certain matters of research in their own country and several of the oountrieg have taken adrantage of this opportunity. China, Bollvia, and Greece have asked for 
such help. I In some cases, notably in the case of Chlne, the tealth orgenization hes helped countries reorganze their vhole rublic heelth adminletrotion. In 1922 and 1903 , on the advice of the Jealth Conmittee, $\varepsilon$ merber of the Teelth section made a study tour of the heelth orgenization end the preralence of enidemic disec ge in the ports of the Far Laet, includine centon, Shenchet, and lew Chane. ${ }^{2}$ His etudy also inoluded the senftary ardinfstration exigting et thet tire in peking. In 2925 the redical Director of the Tent th orcentzotion rialted Fekine and reported to the Fenth Cormittee the results of his alscussions with the vinieter of the Interior. with cther state officiols, vith public herith and medict experts. This croup of offictals and experts was relzed uron in october 1928 to orgenize the linintry of Te: lth of the les,jonal covernment of the Rermbif of ouino t wenkine. It decided to exall Itgelf of the experience of the Jeal th nrendzation of the joucus. On senterber 14, 1929, the secretary-

georotarlat of the League of Vationst International jeulth Yeil 30ok, $102 \%$, Fae 314 2 Becreturith of the Lewtie of Nations: Intcrnational Health Year Book, 1929, Page 1478 
Oeneral of the League of Nations recelved request from the Pozelgn Hinl ter of China for a sanitary misit on from the Health Organization of the League to make aurvey on port health and maritime quarantine. As soon as the Council had approved the cooperation of the Hevilth Organization to ald China in thi. service, the ledical Director and member of the Health Section went to China. These men arrived in Chlna on November 9, 1929, and on the proposal of the Chinese Minister of Health, began a preliminary study on quarantine arrangement at certain ports and otep necessary to the establishment of a national quarantine service, and on the organization and working of modical and senitary inetitution in various oltles and administrative diviolons with special refexence to medical education, the training of anitary personnel, provincial health organizations, the work of the National Epidemtc Prevention Bureau, and the control of cholera and amoll-pox in the Shanghal area.' These subjects were tudied in rarious section of Onlna whlch were suggested by the Chinese Linister of Heajth. The ections of China risited weres

Searetariat of the League of Nations, International Health Year Book, 1929, Page 1480 
Shanghe1, Nanking, PekIng, Canton, Tientgin, Tangtoo, Hangchow, Anung, Ancoy, and wurch. While these offlelel were meklne the above inquiries, the Minister of Education and the Ulnister of Public Health, in the name of the Republic of China, sent a proposal to the League of Wations. The proposal acked that the League collaborate with China in the following ways during the period of reconstruction of her Health Department. 1

1. The Tranafer and Reorganization of Quarantine Service

The Heal th Organlation would otudy, in conjunction with the Transit Organization of the League, messures for the transfer of the present quarantine services from the kinistry of Finance to the vinistry of Health, and their reorganization and technici 1 improvement.

2. The Creation of a Central Field Hetilis it tion

The Hecilith Oreanization would collaborte in the preparation of a detilied plan for Central Field Stition, to which the technlcal hesdquarters staff of the Linicitry would be asolgned, to beoome the nuelous of the future national field heal th servioe.

Pacllities should be provided for study abroad on behalf of Secretcrlat or the Iecgue of litions: Interntional
Health Yoar Book, 1929, Pags 1481 
offlcers selected for important poete in this etation, and an oxpert from the Health Organization sinould be associsted with this station during 1 to orgentzation and Initial derelopment.

3. The Establishment of the First Netionel and Chekiang Hoapitals

The Health Orgenlzation would asoist in planning the first lationa1 and Cheklang Hospltels, which w111 become centers for publio health and medical relief. The National Gorernment will collaborate with the Provinciel Government of Chekians in the establishment of the hognltal at Hangchow, the provincial capital, and this hoopitel would be used as a base for the develogment of a b tem. of provincial health adminletration.

Faollities should be provided for the senior acininistrators of these hompltels to study abroad.

Adrice would be needed in regard to the extension of the preventive activities of the Cheklang Hospital as well as on the extenolon of such avgtem to other areas.

4. Reform of Ledical Education

The competent commission of the Health Organiation would prepare memorandum on the reform of wedical education in rnrlous oountries. Facilitios for stuciy abroad hould be provided for the offlcex who ig to have charge of the post- 
creduate medical instruction, and a League expert should be dolegated to adrise the Hationa) Commi an on on liedicel Education set up by the linistry of Education.

5. The Control of Cholera and Small Pox in the Shanghal Area

The cooperation of the Health Organization of the League, InciudIns that of 1 ts Eastern Bureau at Singapore wag requestod in a oappalsn against cholera and mallpox In the Shanghal area to be oarried on jointly by the health authorlties of the oubdiristons concerned on the initiptive of the Hinletry of Health. I

On Leroh 8, 1930, these proposel and the otudies made by the League's health officials were presented to the Heslth Combltee. The Health Committee approved the entire report and on liay 24, 1930, asked the Hedical Director to Insure the assistance of the Health Organization in cirrying them out.

Socretariat of the League of Nationsi International Heal th Year Book, Page 1483 
Cugasi VI

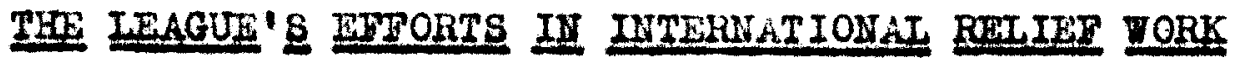


The first private orgsulation with walch the League coopercted wae the Fed Crobe. This vas natural 1nemuch an the ned Cross was firmly eatabIlohed in all well-organtzed countries, anc it had alogy stood for offering help to the needy and distressed Irrespective of color, creed, or nationality, the same principle upon which the Leacue of istions we buflt. As a metter of fect, the E.ed Cross carrled out the vork of the Heclth Division, under the supervision sind control of the Lcague counc1l, before the Ilealth organization was rogerly worked out. After the close of the World War, Europe was in a dire position, rarticularly in Esthonia, Ilthuania, Czechoslovekia, the Kingdoms of the Berbs, Croats and Slorenes, Russia, ind Foland. Disesse and fimine vere raveging the poople, end imnodintely upon ita organ1zation, the Leacue bezen action. Me first step taken was to ask the president of the Internetional Leegue of Red Cross societ1es to deal with tho urgent taok of wlping out the eplaemics recine in Contral

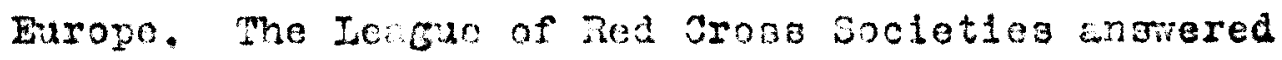
that it could not trike ur the task alone, beccase it wonld be lmpossible to acciro the anount of money and the food and clothing necessnry, under 1ts existing 
organlzation. However, it promised to organize plens for work in the ge farts and also to mkike an international plea for financial alj tiroug each of its nationd orginizations if the Laveue mould promise additionel support, Me Lergde agreed to give suoh support after it wes mocessful in bettine tie Interratiomi Committee of the Ned Cross and the League of sed Cross societies to form a Joint Council. 1 The Council of the League of lfetions felt this vas necessary fox two reasons: It would prowt ovorlapplase and waste of effot, and the nombers of the League of Natlong would more willingly assiot the Rec Croos in ald of 1ts activities. In 1321, in June, the Council of the Leacue recormenced to all covernments which were mombers of the Ieecue of liations to cive the Red Cross assirtance $\mathrm{b}^{2}$

(1) Elvine free trensport and exemtion from customs duties of all supplies sent to the Joint councli for Jistressed Areas!

(2) giving opportunity for the 10001 purchase of foodsturfe and pritrasy necessities at the loweat pricess

(3) giring transport facillties for agents of the Jolnt Council;

\footnotetext{
Seeretarlat of the League of Nations: International Heal th Year Book, 2825, zage 363 2

Secretariat of the League of ivitions: Inteyats of World Cooperation, Page 263
} 
(4) making provialon for the Joint Counc1l to use such public bulldInEs 2 ment be avellable for the houling of children and sick percons.

In addition to the moral support civen and the recomendetion made, a outlined abore, the League Immedlately begon work with the Red Cross Socletles by Elvine financial expport. Grect Britaln, alone, gave to the Ieacue for this purpose 120,000 pounds. A Research Commltee was sent out by the Leacue to make study of the et10logy of typhus fever in kusgla and Poland. 1 This cooperation with the Red Crose Societles, aboolutely necessary at the time, was, however, only temporary. The regults vere so importint and satisfactor; that an International Rellef Union was set up so that the cooperation between the sereral governments and the Red cross through the ald of the Lengue of Netions mfght become permanent and last1nE, rather tian temporsy.

In 1920, Senator Ciraola, president of tire Itolian Red Cross, proposed that an International Reller Union be set up. 2 His proposal was that a permanent organlzation be set up to make the efforto of

\footnotetext{
Seoretarlat of the League of rationes International Feal in Year Book, 1925, Fage 572

2Ibld.. Fage 575
} 
Governments and private organizations prompt and effeotive in the erent of a calamity, such as famine, earthquake, flood, or epldemlca. The ldea of haring all olvilized nations come to the agsiatrince of one distressed was not new. Up to this time, such unforeseen oslamities had been cared for generouply by the Red Cross Societies and by the aid of governments. In many cases ach rellef, because it had to be so hurriedly brought into being, had not been as prompt nor as effective as it could have been if there had been a skeleton organization already exlsting with a fund of money and supplies on hand. It was Senstor Craolo' scheme to have a Relief Union organized so. that the whole machinery could be set to work as soon as ocoasion demended. 1

At the next conference of the Red Crose Societies, held in 1923, otep were taken to promote the soheme, and it wa proposed to offer the plan to the Assexbly and the Councli of the League of Nations. The Assembly and the Councli recelved the plen ferorably and recommended that it be submitted to the member covernmento. A opeolal comittee wa appointed to prepare a draft of the otatute. In 1827, the Council of the League uumoned a conference in whloh forty-one states took 
part. The League of Red Cross Socletles and an International Committee of the Red Cross were represented In an advisory capacity. 1 The convention, which established the International Relief Inton, took 1ta powers from the Preamble of the Corenant of the League of Nations which elve a one of 1 ts reasons for being." to pronote internetional cooperation and to achlere internationel peace and security;" also from Article 23 of the Covenant which states that the League w111 endearor to take steps in matters of international concern for the nrevention and control of disense;" and from Art1cle 25 of the Covenant which say, "the members of the League agree to oncourage and promote the establiahment and coopertion of duly authorized voluntary Iational Red Cross Orgenlation having as purposes the 1mprovement of heolth, the prevention of disease, and the mitidetion of eufferine throughout the world."

The Internetionel Rellef Union 1s open to all Btates, whether members of the League or not, and it operetes within the territory of the rembers or in any place where the members desire it to operate. Worla Cooperation, PaEe 281 
A member may discontinue its memberahip in the Union by glving one year's notice. The Union ia direoted by - General Council, waich appoints an juccutivo Comalttee male up of delegates from all tine menuer state of the Union. The newbers of the union are states, but eaca state appoints lis own delesate. The aotion of this Beliof Uaion in any country is subject to the oonsent of thiut country's government. The ojjects of the International helief union ar stuted in its statutes are:

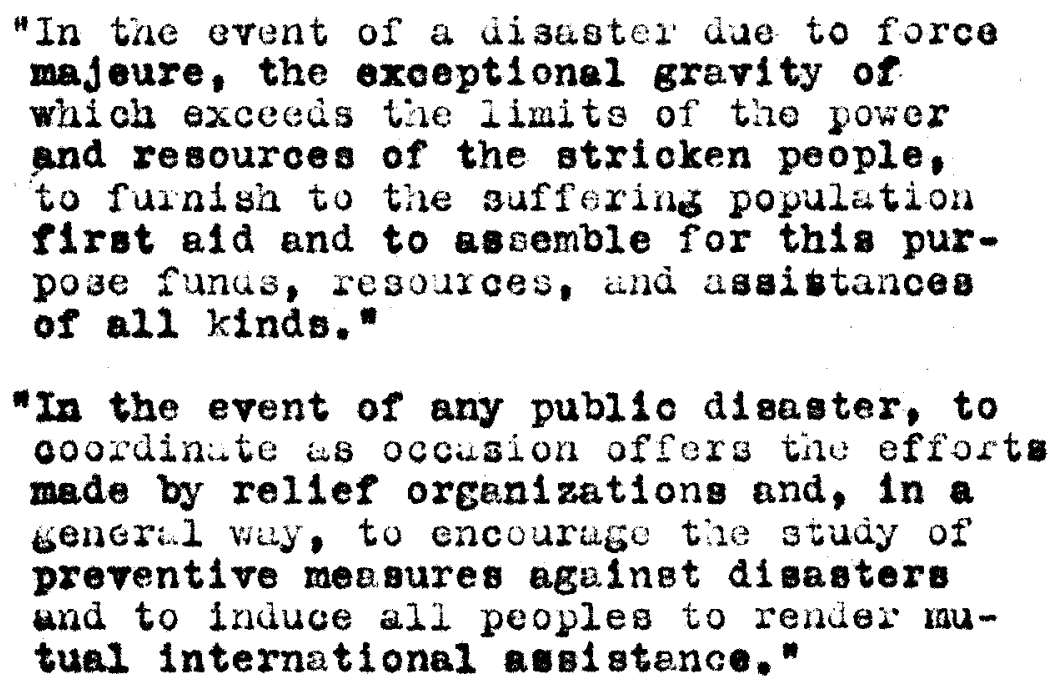

"In the event of any public disater, to coordinite is occision offers tine efforta made by rellef orcanlzations and, in a benerin l vey, to encourage the study of preventive measures agalnst disaters and to induce all peoples to render mutual international asistance."

The Rellef Union has been set up and acts in the orpaoity that 1to initiators hoped. It is a skeleton organization having the facilities and money on hand which enoble it to epring into action promptiy and thus insure the most effective and economioal coorclnation of ralief work. The lnitial fund was 
oecured by having each nember subsortbe shares of seven hundred Swiss frmes erch, the number of ehare belug determined $b_{j}$ the numoer of units asci menber of tho Union contributed to tie bulet of the League of rations, Taus, for iagt noe, a state raye one hundred twonty-five units of the Iengue butcet vould contribute one munarod twenty-five times soven hundred frencs, which would amomt to eishty-geven thousand five huntred solss frencs, to the inltisl fund of the Union. Beside tiis intiel fund, the resources of the Union consist of voluntar eranto mode by covornments, of private contributions, and of donetions and bequests of all klnde. Of to the present time, the Inlon has been xatifled by tilrteon nutione, thoxch all of the sures he not yet been subscribed. In founcine the Internetionel Rellef Inton, the League of vaticre establighd its emerency and rel1af work to cone extent end put its relations with the nec crose and other privete organizetions on a permencet and contractual be bie. 
CHAPTER VII

CONCLUSION 
In the foregoing pages I have endearored to Bhow how the Yeal th organlzation of the League of Nations works in cloge harnony with the Internetiona) Burecu of Public Health and with the League of Red Cross societies. It does not in any way tr, to replace these bodles; in fiat it depend on these agencles and on all the agencles of the Individual governments to support its work. In the bittle agalnat disease there is a place for all agencles. The Health Organization tikes this into congideration in thet it invites all netione to join it in wlplng out disease. The United states of America end the Union of Socialist Soviet republics have both accepted the invitction of the League to join In its heilth program, thus deciding not to subordinate their cooperition in health ters to politicel conolderations. 1 As a refolt of the joining of theseetwo nations in the health program of the League, a rery importent union has been formed, the first of 1te kind in the history of the world. It 1 a union of all of the important atates in the world and most of the mall one., who heve marshalled thelr forces together in the grect conbat aeginst di mease. 
Thlo comine together of all of the world power In a fleld where cech has 011 to gain and nothing to. lose has another advantege beside offering stronger defense egefrst diseese. In their mutuel interest in heelth the nationg meet in a kindly and cooperutive splrit, and it is hoped that they w1Il here learn how to arbltrate and work out the1r problems peaceably.

Thus, the Health Organization 18 serving the vorld in two way in flghting diseate more effectively then has ever been done before, and in creating the cood will and mutual understanding that 18 so necessary to world pecoe amone nations.

In all of 1 ts work the Health Organization has observed the principle of cooperation between $e 11$ stater. Its work hes been with all peoples, 1rrespective of $r$ ce, netionallty, or creed. Its only gulde is wherein its work $\$ 111$ most benefit mankind. 
BIBLIOCTIET 
American Fed Cross: Bulleitn of the Lesnue of Bed Grose Sootetien Washington, Goternment Printing off10e, 1910

Hubbard, Uroula P.: The Gooperation of the Undted Stcteg vith the Lee aue of Vations and Tth the International Iaboux oreanization roroester, Masechusette, Cornegie Endowment for International Peace, 1931

Rookefeller Poundetion: Annual Report of the Rookefelier Boundetion Vew York, RockefoIler Foundation, 1223

Secretiriat of the Leacue of Nations: The $1 \mathrm{mg}$ and orrandzation of the League of Ietiona Genera, 1929

Secretariat of the League of Natione: Ten Yeare of World Cooperntion Cenera, 1930

Secretarlat of the League of Nationa International Ieolth Yeax Book, vole. I-V Genera, $\frac{1925-29}{192}$

United States Government: Treatieg of the United Stctes

Volume II, weohington, 2910 Volume III, WashIngton, 1913 Gorernment Printing office

Worla Peave Foundationi Ramphlet Series

Tolume $v, 1922$

Voluwa VII. 1924

Volo. VIII-XII, $1225-29$

Boston

World Peace Poundation 
Baker, Raymond Stannard: Woodrow W128on and the World Setterent Vew York, Page and Company 1922

Bessett, John Spencer:

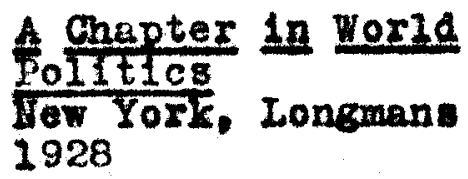

Beer, Georce Loula:

African Questions at the Eeroe conference hew York, Loomilian Compeny 1927

Buel1, Raymond Lesile:

Internationel Relations Hew York, Henry holt and Company 1925

Duggan, Stephen Plerce:

Leasue of Nationg Boston, AtIantic Honthly Press

1929

Pioner, Irving

Ameriog's Interest in vorld Peace

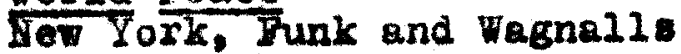
1924

Iaworth, Paul Leland:

Hershey, Amoss

The United Statep in our OTn Times Iew York, Serdber's Song 1920

The Espential of InternationeI Tublic La ̃ Tow York, Yeomil Ian compeny 1927

House, Edward and

Seymour, Charlebs

That Really Heppened at Feria

Now York, Serlbaer's Sone 2921

Joseph, Lawrencel

The sooiety of Hations London. Oxiord prese 1929 
Uarbure, Thoodores

Morrow, Dwight:

Yower, Edmund,

Lyer:, Denny : :

Lyers, Dennys:

Rappard, T1121am E..

Swoetser, Arthur:

Sweeter, Arthur:
Leacue of Vationg

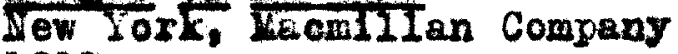
2027

The Sootety of Froe States

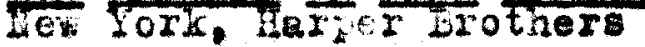
1918

Internatlonel Gorernment Boston, Heath erd Compeny 1931

Hondbook of the League of Ations S1.2ce 1920 Bogton, WorId Peace Foundation 1930

Nine years of the Learue of rationg--1020-1928 30Eton, vorIa Eece Foundation 1929

The League of Nations as an Historicil Fact Waghington, Carnegle Endowment for Irternetionel Peace 2927

The League of Nations at Work Hew York, Iacrilifo Company 1920

The Irist Ten Yoars of the League af Netions Washington, Carnegie Endowment for Internetiont I Eeace 1922

Tomperley, Harold W. V.I
A IIstory of the Peace ConIexence London, Froude 1920 


\section{PFAXIODICALS}

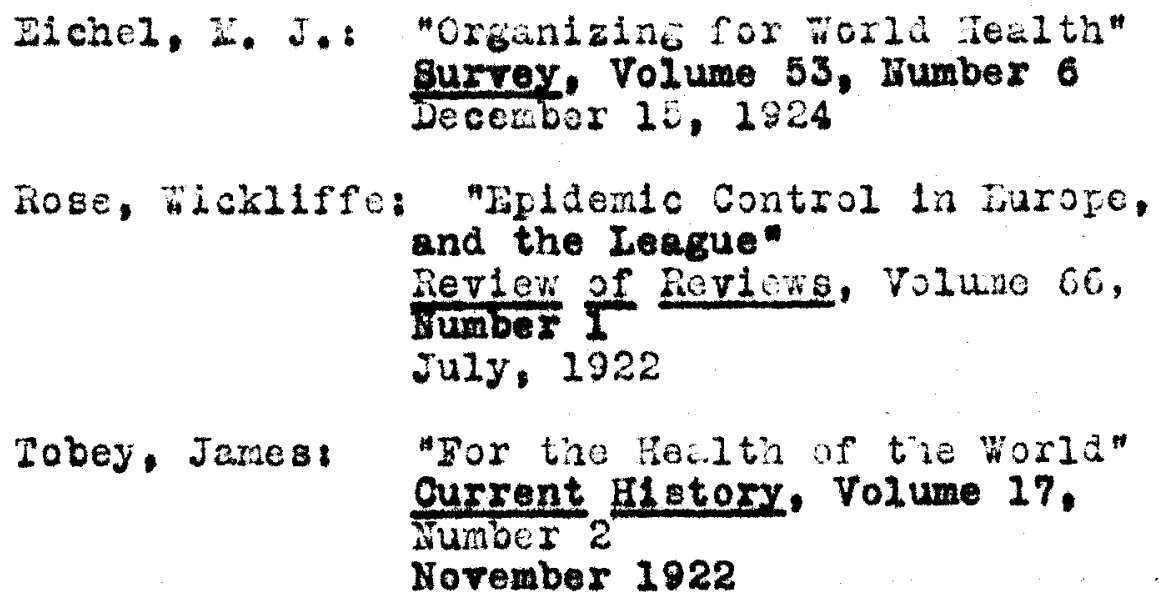

Winelow, E. A.: "The Jorld War ABainst Diseage" Iygelá. Volume 4, Nunber 7 Juty, 1926

Iditorial:

"Health Organization of the Leagie of Futions"

Rerlew of Reviews, Volume 74, tidinber 2

August, 1926

IDdtorial:

"The Heal th Comalttee of the Zecious of rictions"

Solence, Volume 60 , Number $\mathbf{3 5 5 0}$

Septenoer 12, 1924

Editorial:

"A Watch on Disease"

Solence, Volume 68, Number 1768

Novenoer 16, 1928

La1torial:

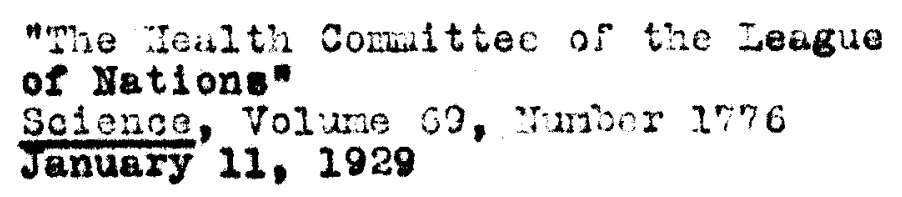

